\title{
Powerful knowledge and the textbook
}

\author{
Nicky Platt* - UCL Institute of Education, UK
}

\begin{abstract}
This article draws on experience both within commercial textbook publishing and on textbook-development projects at the UCL Institute of Education to interrogate the current dynamics of 'neoliberal' edu-business (after Ball, 2012). The author discusses some damaging limitations inherent in publishing coursebooks predicated on what Young and Muller (2010) term a 'Future 2' approach, and outlines the potential benefits of classroom materials that allow 'knowledge' and 'text' back in. The discussion is situated mainly in the context of England, where a subject-specialist approach to teaching and learning is strongly advocated in the policy environment.
\end{abstract}

Keywords: powerful knowledge; textbooks; subject-specialist; social justice; curriculum

\section{Prologue}

The scene opens in Alan Bennett's The History Boys with a man in his forties, a spin doctor named Irwin, addressing a small group of politicians (Bennett, 2004). He is teaching them how to obfuscate. 'Paradox works well,' he argues, because it 'mists up the windows', and he exemplifies his advice with the soundbite 'The loss of liberty is the price we pay for freedom' (ibid.: 3). In his next line, Irwin reveals that this is a technique he learned at school, through teaching. Then begins an extended flashback to Irwin's early days as a teacher. Enter Mrs Lintott, Dorothy, a teacher of many years' experience whose primary concern is that her boys (in this single-sex, North of England grammar) 'know their stuff' (ibid.: 9). Faced with the Headmaster's desperation to get as many of the boys into Oxford and Cambridge as possible, in an undisguised effort to push the school up the league tables, Mrs Lintott suggests that an extra term's coaching should comprise 'more of the same' (ibid.: 8). She counters the Head's objection that 'something more is required' (ibid.) with the belief that 'Plainly stated and properly organised facts need no presentation, surely' (ibid.: 9). In this scene, where she stands in contrast with the forms of cynicism embodied by the Headmaster and by Irwin in the opening vignette, the audience's sympathies are with Dorothy and her understated use of irony. Indeed, throughout the play the audience is never invited to question Mrs Lintott's unflagging commitment to her students and to the truth of her subject. And yet the Headmaster is in one sense right: something more is required. When Rudge, with memorable concision, gives his definition of History as 'just one fucking thing after another' (ibid.: 85) the moment encapsulates the audience's uneasy sense, for which the play has no resolution, that something pedagogical is missing.

Irwin's response to that lacuna, as a new and very young teacher (15 or 20 years before his career change), is to add 'singularity' to the mix (ibid.: 18): to coach the boys towards competing with the private-school 'thoroughbreds' (ibid.: 20) by nudging 
their bored and sleepy examiners awake with casuistic, counter-discourse arguments. In response to one pupil's defence that the arguments he had put forward for the origins of the First World War might have been those expected but are 'all true' (ibid.: 24), Irwin counters 'What has that got to do with it? What has that got to do with anything?' (ibid.: 25). 'History nowadays,' he later asserts, 'is not a matter of conviction. It's a performance' (ibid.: 35). Of course, in saying this, Irwin is himself performing, and it is unclear whether any conviction lies behind his stance. Irwin is not the villain of this piece; if anything, he is the anti-hero. His intentions are primarily good: he is trying to help his students to access what he and they perceive to be the best higher education opportunities open to anyone, and his approach 'works'. It is arguably a premise of the play that without Irwin's added spin, the pupils would have remained, in their Headmaster's damning phrase, 'a little ... ordinaire' (ibid.: 9), and at a less prestigious redbrick university.

The question is, at what cost? What price, as director Nicholas Hytner terms it, Irwin's 'swashbuckling relativism' (cited in Crace, 2006)? There is a sense, as The History Boys proceeds, of a long, quiet fall from grace. When Lockwood asks 'Is nothing sacred, sir?' (ibid.: 39), it is in a tone of mock reproach, but the question lingers. In brief confessional soliloquies after the interviews, Scripps tells how he attended the college chapel in a 'genuine act of worship' but knowing 'it would do [him] no harm with the college', and Posner, a Jew, explains how - as he had been advised to do if the 'topic' of the Holocaust came up - he 'did play it down' and was then praised for his 'sense of detachment' (ibid.: 96). As the close of the play reveals, the boys go on to an array of careers in business and the professions. One builds a career founded on 'telling highly paid fibs' (ibid.: 107), another is a journalist (much the same construct in Bennett's terms here) and one, Posner, the archetypal scapegoat:

lives alone in a cottage he has renovated himself, has an allotment and periodic breakdowns ... He has long since stopped asking himself where it went wrong. (ibid.: 108)

\section{Introduction}

Any links from the Prologue above to the world of educational publishing may not be immediately apparent. The History Boys is not a play about textbooks. The characters of Dorothy and Irwin can, however, be used for the purposes of the argument that follows as fictional embodiments of the two most prevalent approaches to teaching in recent history, in the UK and beyond, personifying what Michael Young and his coauthors have termed the Future 1 and Future 2 orthodoxies. Their shadows fall across the discussion that follows and their names are invoked from time to time to illustrate the developing argument.

This article looks first at the vexed status of textbooks in education in the UK, giving the grounds for a particularly British case of 'textbook-denial'. The discussion then charts recent attempts by the UK government and a variety of lobbying groups to bring textbooks back in from the cold, and takes a brief look at the evidence used to justify this initiative. It opens up the wider context of an attempt to reclaim the curriculum from a heavy focus on skills by 'bringing knowledge back in', then problematizes this by distinguishing between a largely performance-driven imperative and Michael Young's advocacy of a knowledge-led curriculum for social justice. Young and Muller's 'three futures' heuristic is outlined here (Young and Muller, 2010). The second half of the article uses their construct as a lens through which to view contemporary textbooks 
and explores a representative example of the prevailing 'Future 2' UK-produced global coursebook. The discussion concludes by posing a set of questions marked for my own attention as a textbook publisher and, by extension, for the attention of anyone involved in curricular and materials design.

\section{An anti-textbook ethos?}

Textbooks are a particularly contested site in the UK. In his 2001 study of geography, history and social studies textbooks, Bill Marsden devotes a chapter to what he calls the 'British anti-textbook ethos' (Marsden, 2001: 55). This culture has developed, he surmises, from teachers' and in particular education tutors' sense that textbooks are usually both inadequate as classroom tools 'enacting' the curriculum and potentially very damaging to the 'learning' dynamic. Researchers commenting later have tended to concur with Marsden's thesis (Issitt, 2004; Harwood, 2014; Biddulph et al., 2015). In some cases such commentators have added subject-specific perspectives of their own, leading to a body of literature that, in sum, attributes the UK's culture of textbookdenial to four key factors, which are discussed below.

The first factor is textbook quality. Textbooks are understood to be structurally and methodologically flawed (Hadley, 2014); to comprise watered- or dumbed-down content (Marsden, 2001); to cater for the lower- or middle-achieving pupil, to thereby focus on low-level activities (Marsden, 2001) and to pay lip-service to differentiation (Lambert, 1999); to be poorly designed in terms of page layout and readability (Lambert, 1999; Marsden, 2001); and to contain many out-of-date or 'irrelevant' input texts (Thornbury, 2013; Harwood, 2014).

The second factor is both theoretical and ideological. It relates to two separate forces within educational theory and practice: the development of 'progressive' education, which derives in large part from the theories of Dewey, Piaget and Vygotsky and, later, the practice of Freire; and the 'new sociology', springing from Bernstein and established by Young's 1971 volume Knowledge and Control (see Marsden, 2001; Thornbury, 2013). These twin forces have given rise to a strand of criticism that dates back to Rousseau (at least) but which gained particular traction in Britain in the 1960s and 1970s (and was sanctioned by the 1967 Plowden Report) - that textbooks maintain a reactionary status quo in a number of ways. Textbooks, by this account, trade in dogma and bias, and exclude minority or simply non-Western voices (Gray, 2010; Thornbury, 2013; Gray and Block, 2014). Furthermore, they promote uncritical responses from pupils and an unprofessional approach in teachers, significantly limiting the creativity and autonomy of both (Lambert, 1999; Harwood, 2014; Grammatosi and Harwood, 2014; Biddulph et al., 2015). In short, they prop up the figurehead authority of the teacher and privilege the conservation of subjects above the needs and interests of the pupil (Marsden, 2001).

Many 'learner-centred' approaches to education developed at around this time, supported in some measure (with a certain irony, as things turned out) by the focus of sociologists like Michael Young on the socially constructed nature of knowledge. Following Young's highly influential Knowledge and Control (1971), textbooks could be seen (and were portrayed by some) as one of the most pernicious reifications of 'knowledge of the powerful' (ibid.). In some circles, this argument maintains its force, with the sustained influence of the work of Michael Apple, for example, who continues to argue along Foucauldian lines that textbooks promote 'official knowledge', meaning that 'cultural domination is a fact of life for millions of students throughout the world' (Apple, 2014: 52; also Larson et al., 2010; Giroux, 1997, cited in Thornbury, 2013). 
The third factor is resistance to the power and influence of the textbook publishing industry, particularly in the realm of examinations-focused textbooks (Ball, 2012, 2017; Apple, 2014; Hadley, 2014). The trend in recent years in the UK has been for examination boards to either develop an exclusive partnership with an established publishing house or to plough resources into their own publications subsidiaries. These publishers then commission textbooks that are explicitly geared to preparing pupils for 'success' in one of a suite of high-stakes examinations (primarily, GCSEs at 16 and A levels at 18). The materials are often written or series-edited by one of the chief examiners with responsibility for setting this particular board's exams, and are then endorsed by the same awarding body. This is big business (Watt and Newell, 2011) and as such it is well organized and well defended, and difficult for teachers to resist. Crawford and Foster argue that teachers are increasingly choosing textbooks based not on professional considerations of content and approach but the expedience of having all possible assessment items covered (2006). This has 'a profound effect on teacher choice and teacher autonomy' (ibid.: 93) to the extent that such endorsed textbooks may be a greater factor in some classrooms in the way teachers enact the curriculum than the teachers' own professional, pedagogical choices. Wider empirical research is needed to determine whether this reported trend is indeed occurring and what the implications might be.

The fourth factor in the UK's anti-textbook culture is the now widespread availability of rival classroom tools and resources. These are mostly either digital in form or in hosting, and a significant proportion are both generated and shared by teachers and teacher-led groups rather than by publishers. It can be argued that many of these new resources are liable to all of the criticisms traditionally levelled at textbooks. They are, additionally, compromised in terms of production values, curricular coherence and progression, and pedagogical efficacy by amateur (and often minimal) editing, design and hosting/production.

It is also important to point out that domestic textbook sales are not in the downward spiral this anti-textbook picture would logically suggest. For 2016/17 the UK Publishers Association reported that domestic sales of educational resources in print were up 1 per cent on the previous year's sales - a very modest rise, but an increase nonetheless (Publishers Association, 2017) - and their latest estimate is that the current UK annual expenditure on printed educational materials stands at $1196 \mathrm{~m}$ (Eyre, 2018). Despite this, a certain perception endures that the internet and ed-tech are ushering in a new post-textbook epoch.

Probably because of the prevailing anti-textbook ethos outlined above, research on textbook quality, patterns of use, piloting practices and so on is notoriously thin (Marsden, 2001; Foster, 2011; Lee and Catling, 2016). This is despite the best efforts of some notable individuals and groups, including in the geography and history education communities (listed in Marsden, 2001, and Crawford and Foster, 2006), as well as the Publishers Association, collaborating in earlier days with Margaret Maden (1990s) and more recently with a wide range of political, academic and commercial stakeholders to set all those involved in UK education a 'Textbook Challenge' (Publishers Association, $2016 a, b)$. The topic of textbooks does not appear to have high status among the academic community; it receives little funding, and some of the research has been subject to charges of being 'under-theorized' and lacking in methodological rigour (Nicholls, 2005; Gray, 2010; Harwood, 2014). Precisely because of the paucity of the research base, however, it is important not to overstate the case for the anti-textbook ethos that is anecdotally so prevalent. As we have seen, textbooks are still being bought and used, and even their most eloquent and vocal opponents consider them 
(and not only within contexts like English language teaching (ELT)) 'a fact of classroom life' (Lidstone, 1992; Thornbury, 2013).

\section{Bringing textbooks back in}

It is equally important not to allow Britain's perceived anti-textbook ethos to be exploited by certain groups or politicians as an opportunity to castigate teachers and teacher-educators for what can be portrayed as unthinking bias. In recent years, efforts have been made by the UK government and various lobbying groups to achieve two objectives that can be welcomed (Independent Teacher Workload Review Group, 2016; Cambridge Assessment, 2016; Publishers Association, 2016a,b, 2017). The first is to make teachers aware that there are good textbooks available and equip them with the tools or criteria to identify these, and that using good textbooks effectively can both improve their teaching and optimize workloads. The second is to make publishers take greater responsibility for the quality of what they produce. One of these groups is Cambridge Assessment, led on the research side by Tim Oates. To get this message out they have produced a clear and thoughtful policy paper 'Why textbooks count' (Oates, 2014) and a set of principles 'for designing high-quality textbooks' drawn up in conjunction with a number of education practitioners, academics and publishers (Cambridge Assessment, 2016). Together these documents offer both users and producers a solid rationale for the continuing role of textbooks in UK schools and a set of practical, well-considered guidelines for improving the structure, content and design of these materials.

However, the 'evidence' for the benefits of using textbooks is not as clear-cut as some of textbooks' most recent advocates (most influentially, Cambridge Assessment and the current UK Department for Education) might have us believe. Often quoted is Cambridge Assessment's claim (2016: 6), based largely on Reynolds and Farrell's (1996) transnational comparison work and supported 'in [their] work around the world', that 'it is the best teachers who are the most supportive of the use of high-quality textbooks and materials'. This is not exactly what Reynolds and Farrell conclude - rather, it is an extrapolation, doubtless well-intentioned, of the authors' stated findings that one feature of higher-performing jurisdictions (in the 1990s) is:

The use of the same textbooks by all children, which permits teachers to channel their energy into classroom instruction and the marking of homework, rather than into the production of worksheets that is so much a feature of English teaching. (1996: 56)

This is not the same as proving that 'the best teachers' use textbooks. Nor, from the statistics laid out in this study, is it possible to isolate the impact of the use of textbooks in any of the very divergent jurisdictions and to come up with anything more categorical than the proffered finding above. But more concerning than this stretching of the evidence is that this 'fact' is being repeated uncritically but with critical intent. Party-political voices speak alongside and across the Cambridge project and portray the traditional resistance to textbooks from teachers and education tutors far more belligerently, labelling it 'ideological hostility'. This is the phrase used by Nick Gibb, the UK's current Minister of State for School Standards, in his preface endorsing Tim Oates' policy paper. It betrays the view of this government team that higher education institutions (HEls) responsible for teacher-education programmes are blinded by ('progressive', left-leaning) ideology and ignore the real evidence (Oates, 2014). As we have seen, however, solid evidence is still lacking and needs careful interpretation. 


\section{The curricular context: A knowledge-led future?}

How might the education community work towards precisely those aims identified by Cambridge Assessment - supporting teachers in their practice by using textbooks, and supporting publishers to improve what they offer - and yet avoid further entrenching anti-textbook resistance? One way of moving the debate on, proposed here, is by taking a closer look at the textbooks in our classrooms today through the lens of Young and Muller's 'three futures' model, which has the concept of 'powerful knowledge' at its core. The political and other lobbying for textbooks discussed above is part of a much broader agenda to reclaim the curriculum from 'skills' and hand it back to 'knowledge'. There is a clear drive - in Young's famous phrase - towards 'bringing knowledge back in' (Young, 2008) and taking renewed interest in the curriculum. This move is spearheaded by Nick Gibb and supported by a number of think tanks (e.g. Policy Exchange, Institute of Ideas), as well as high-profile school leaders (e.g. Rachel de Souza and Christine Counsell, of the academy chain Inspiration Trust), exam boards (e.g. Cambridge Assessment) and, indeed, the head of the UK's education regulator, HM Chief Inspector Amanda Spielman, who advocates curricula 'focusing on a rich foundation of knowledge' (Spielman, 2017).

I would argue, however, that it is important to make a very clear distinction. This distinction is between taking forward Michael Young's agenda for social justice, which advocates 'powerful knowledge' as the pedagogical right of all children and students, and a version of the 'knowledge-led curriculum' that allows Young's highly nuanced arguments to be lumped together with paraphrased extracts from E.D. Hirsch (2015, cited in Cruddas, 2017) in the name of equity but with far more of an eye on the UK's performance in the global league table of high-stakes assessment (Gibb, 2015, 2017). To be clear, the advocates of a turn 'back' to knowledge are not all complicit in this kind of elision. But Michael Young's recent observation that 'the idea of a knowledgeled curriculum for all is a much bigger and more difficult issue than any of us want to admit' takes on great significance (2017). Teachers and the authors of textbooks need to be clear about what they mean by a knowledge-led curriculum, and equally clear about what they do not mean. It is here that Young and Muller's 'three futures' scenario becomes very useful.

What, therefore, does the 'three futures' idea involve, and how might it offer a productive way of revisiting the textbook debate? The 'three futures' scenario is not a fully worked out curriculum model, nor is it a prescription. As we have seen, it was originally offered by Michael Young and Johan Muller in 2010, and taken forward by colleagues, including David Lambert, as a 'way of thinking about curriculum' (Young et al., 2014). It is not a description of successive historical periods, either in the UK or in any other jurisdiction, and it is not intended to be sequential. Thus, one could conceivably find various features of Futures 1,2 and 3 coexisting in different ways in many schools today. It is the case, however, that the framework can be used (carefully, and in part) as a heuristic to distinguish various 'moments' in education policy and practice. So what is meant by each possible curriculum 'future'?

Future 1 describes a traditional, conservative approach to education. Teaching is organized into time-honoured, 'given' school subjects, which are understood to derive from established university disciplines. The prevailing pedagogy is teacher-led and transmissive, predicated on an undersocialized understanding of what knowledge is and open to the charge of promoting 'the transmission of fixed, elite, uncontested cultural knowledge' (Lambert, 2018: 132). The 'informal, local, experiential and everyday knowledge' pupils bring to school is largely ignored and little valued (Young and Muller, 
2016: 12). To give Future 1 a face, let us remember Dorothy Lintott in the Prologue and her 'plainly stated and properly organised facts' (Bennett, 2004: 9).

Future 2 describes a consciously 'progressive' approach, with a focus on learning rather than on teaching (what Gert Biesta (2005) has called the 'learnification' of education). Future 2 pedagogy is therefore child-centred, positioning the teacher more in the role of facilitator ('guide on the side' or even 'peer at the rear' (Biesta, 2017)) than as locus of subject knowledge and authority. There is a deep frustration with subjects as the traditional building-blocks of the curriculum, and a concomitant enthusiasm for cross-subject 'themes' or 'topics' to organize learning, accompanied by a commitment to generic pedagogic practices and tools. The classroom emphasis is on skills (particularly 'learning to learn') and competences, in pursuit of what is often termed '"relevance" to learners' (Morgan, 2018: 114) or, in Jan Derry's phrase, 'a reductive politics of interest' (2018: 87). Knowledge is understood to be entirely or largely 'constructed' and enforced 'from above', less authentic and valid than the preexisting experience that the pupils bring to school, and the concept of universal truth is regarded with deep suspicion. There are shades of Irwin here (Bennett, 2004) and his well-meaning but ultimately cynical and reductive tutoring.

Future 3 embodies the argument that the role of knowledge in education, and of the subject-specialist role of the teacher in education, needs to be recovered and reconfigured. It appears to represent a movement to reconcile what is useful, and what does not need to conflict, in both 'conservative' and 'progressive' approaches. In Future 3 , teachers can, and should, employ engaging or active pedagogies to develop pupils' knowledge and to teach important skills. Equally, teachers should harness a pupil's 'everyday' experience in their teaching, but it is teachers' pre-eminent responsibility to take pupils beyond what they already know or can acquire in their lives outside school. Subject boundaries are understood to be neither wholly 'given', nor wholly arbitrary after Bourdieu (Moore, 2004), but nonetheless necessary. Similarly, it is understood that although all knowledge is (of course) socially constructed, some types of knowledge are more 'powerful' than others, and that it is the main purpose (and should be the overriding priority) of schools to give all pupils access to this knowledge.

'Powerful knowledge', as the cornerstone of Future 3, is usually based on evidence, is conceptual, codified and theoretical, and has systematicity. Powerful knowledge is dynamic and changes over time, evolves in unpredictable ways, and is always open to challenge, but it is nonetheless the most reliable we have. Powerful knowledge usefully sits within (and sometimes across) subject boundaries and relies on university disciplines serving as communities of specialists to act as originators and conservators. It usually lies outside the 'everyday' experience of both the pupil and the teacher, often defying common sense, and is therefore often difficult to acquire, requiring teaching and studying rather than quasi-automatic learning (Young and Muller, 2016; Biesta, 2017). Most crucially, powerful knowledge is the 'pedagogic right' of all pupils, giving them access to knowledge beyond the everyday and experiential - 'the parochialism and limitations of our personal experience' (Sehgal Cuthbert and Standish, 2017: 142) - and thereby affording every pupil opportunities far less limited by the individual's 'home' circumstances.

\section{Textbooks through the 'three futures' lens}

What we shall refer to as 'Future 2' textbooks are now, arguably, the norm in the UK for many subjects. It is also the absolutely standard model for UK-produced 'global coursebooks', defined by Gray as 'that genre of textbook which is produced as part 
of an incremental English language course designed for the global market' (2010: 1). These various manifestations of 'Future 2' textbooks are, of course, a reaction to the kind of 'Future 1' textbooks that many of us experienced when we were at school, and that some of us will still encounter when visiting school systems in the Global South or in former Soviet countries, for example. These very traditional textbooks tend to be encyclopedic both in appearance and in intent: Rudge's 'one ... thing after another' in our prologue (Bennett, 2004: 85). They comprise long passages of dense text, 'run on' rather than organized into clear lessons or units; few images, normally very small and clumped together (originally in order to keep printers' costs down), and minimal use of colour or design features to lift the text. Future 1 textbooks have lists of tasks rather than activities, usually taking the form of comprehension questions occurring routinely after the end of the narrative or explication. Attempts to engage the pupils' interest take the form of paternalistic address of 'the reader' ('dear reader' remains common in some cultures). The teachers' needs are served by teacher guidance that is usually restricted to a list of the 'right answers', if it exists at all.

When put like this, it would be churlish not to be grateful, in many ways, for the advent of the 'Future 2 ' textbook. In Future 2 textbooks, long, dense and often very dull texts have been replaced by shorter texts written to be accessible and sometimes (and increasingly) taking into account research into grading language load. The material is organized into clear 'learning units', usually in a double-page spread per lesson. The content of each lesson is less text-based and channelled more into a variety of visual displays of data, photographs and illustrations (as well as decorative images), zoomed to a size that enables the pupil to actually read the detail. The text itself is often carefully 'scaffolded', using graphic organizers and call-out boxes, designed to make reading more 'fun' and the content more accessible to a variety of 'types' and 'abilities' of learner. The pages are enlivened by a whole host of design features, and a full colour palette, in an attempt to engage and sustain the learner's attention.

In place of the Future 1 lists of comprehension questions, Future 2 textbooks boast an array of 'learning activities'. These are spread across the layout and are intended to be undertaken at various planned intervals in the lesson, in an attempt to help maintain pace and interest in the lesson and thereby optimize the learning achieved. Learners tend to be addressed as equals rather than condescended to or admonished. The purposes and structure of the learning-work they are being asked to complete are both made clear, creating an implicit 'bargain': do this, this and this, and by the end of today's lesson you will know this, this and this, and have these skills. Similarly, in the accompanying Teachers' Books, teachers are addressed respectfully, supported at every stage in the lessons they are to teach (or 'deliver') and their work is carefully scaffolded too so that teachers of all levels of ability and experience can access the guidance.

There is much here to applaud and little to advocate a return to 'Future 1' materials. But let us take a closer look at an example of Future 2 materials. Since, as a textbook publisher, I have long been 'complicit, imbricated and compromised' in the neoliberal dynamics of this industry dominated by 'edu-businesses' (Ball, 2012: xiii), it seems important to take as my example materials for which I bear some responsibility. This is an extract from the marketing material of a multi-level, multi-platform course I commissioned in 2013 as a Publisher at Garnet Education. It is designed to teach English to teenage and young-adult students, from beginner to intermediate levels:

C21 is a groundbreaking five-level general English course that integrates

21 st century skills and academic skills to ensure that students have the 
skills they need for study, work and life ... Skills are levelled in a way that makes them accessible from A1 level, with students introduced to basic study skills, classroom language, and a proactive, self-reflective, creative approach to learning and class interaction. This ensures that students are not just passive receptors of language instruction, but active communicators responsible for their own development. The activity types within each lesson put the students at the centre of the learning process and require them to bring their own ideas into the classroom, to bring their critical faculties to bear on texts and tasks that can only be completed through successful teamwork and cooperation. (Garnet Education, 2018)

There is much here that a Future 3 approach to textbook publishing would retain. Indeed, students should be 'active' and not 'passive receptors' and use their 'critical faculties'. What students bring to the classroom should be respected and used in a productive and appropriate way. It is also right that students take responsibility for their own attitude to learning and some level of responsibility for what they do indeed learn. And yes, in the classroom and as preparation for university and the workplace, they should be developing teamwork skills and learning to cooperate. Nonetheless, these are classroom resources, not self-study materials. However 'proactive' the students are, and however 'learner-centred' the underlying pedagogy, the students cannot do this on their own. There is a teacher in this classroom and this teacher is teaching, not delivering 'language instruction', which this blurb posits as the only alternative to active, communicative learning. In reality, the lessons that use C21 will be equally dependent on the individual teacher's subject knowledge and professional expertise as on what the coursebooks can do to encourage the students' active learning.

The word 'skills' is repeated like a mantra, but 'knowledge' is nowhere to be seen. Of course, the acquisition of a range of listening, speaking, reading and writing skills is absolutely central to language learning. There is a clear and positive recent history of practitioners and publishers focusing on these skills, in order to enable students to communicate in that language, and often to study in it and to work and contribute economically by using it. And they have done so precisely in order to move away from the elitist and often ineffectual transmission approach of Future 1 institutions, with their heavy emphasis on the rote-learning of grammar rules and studying the written texts of dead, white, foreign males. However, as Shirley Lawes discusses, this does not mean that the subject does not also have 'powerful knowledge' as its cornerstone: 'knowledge of language, knowledge and understanding both of the structure of the language itself and of the social, historical and cultural contexts in which it has been or is currently used'. She argues:

The abandonment of cultural knowledge in favour of linguistic 'skills' in order to make foreign languages 'more accessible' had the effect of robbing the subject discipline of a defining feature and emptied the study of foreign languages of its intellectual content. (Lawes, 2017: 41)

A similar trend is the disguising, sidelining or simplistic treatment of grammar in many UK-published global coursebooks. This is in part an attempt to make them more engaging and accessible to all learners, but often results in lessons being structured around 'grammar McNuggets', in Thornbury's aptly anti-neoliberal phrase (2013). This means that fewer students now have to suffer the tedium of rule-learning, Future 1-style, which is likely to stay in the mind only as inert content. But it also means that students are frequently left unsupported, with learning that we could classify as instrumental 
and functional rather than deep and dynamic. Equally, as with textbooks across all subjects, the dominant Future 2 trend in ELT towards shorter and/or 'chunked' texts has meant that students encounter far fewer opportunities for extended reading what Rex Walford in 1995 dubbed the 'strange case of the disappearing text', cited in Biddulph et al. (2015). The implications of this have yet to receive sustained scholarly attention, but the need is clear.

In order to explore some of the positive and negative features of the Future 2 textbook, and to perhaps learn some lessons for a Future 3 alternative, let us do a brief analysis of a sample unit from the C21 Level 2 Course Book (marketed at languagelearners at Elementary (CEFR A1+, IELTS 2.0+) level) (O'Driscoll and Hughes, 2016). Unit 4, entitled 'Performance', opens with a title page, two-thirds of which is taken up by a scene-setting photograph of a professional woodwind trio performing on stage. Under the photograph is a very short 'talking point' (intended as a unit 'appetizer') and below this a table of what in this course are called 'targets', but which in other courses might be labelled 'learning objectives/outcomes', in the form of can-do statements. It is standard in ELT courses to have such tables, laying out the vocabulary, grammar and reading/writing/listening/speaking 'sub-skills', but this course adds a column for 'C21 skills'. C21 skills, the Introduction explains, 'cover academic skills, 21st century skills and study skills', which is quite a broad categorization. In this unit, the C21 skills the students will hopefully acquire are listed as: 'organizing information; improving performance; making ethical decisions; the culture of time; assigning tasks'.

In line with all units in this course, the body of Unit 4 comprises five sections, each of which is either two or three pages in extent, and closes with four pages devoted to 'in-depth practice' of C21 skills (Introduction). The style of layout is the now classic Future 2 'magazine' format, with full-colour, bled-off images. Unlike some textbooks I have seen (and published), however, the pages are not overdesigned at the expense of text. There is what I would consider to be appropriate page space given to input texts - texts that are intended to be read by the students - to allow for the kind of extended reading that is manageable for a language-learner at this level. These texts are well structured to meet the vocabulary and grammar targets stated. I would judge that many students would find them sufficiently engaging to stay on-task and conceptually entirely accessible. However, given that this course is primarily designed for older teenage and young adult learners - who are at a relatively early stage in their Englishlanguage but not in their education overall - and that preparation for academic study is a key part of what this course claims to offer, the texts are in fact too readily accessible. If students are to encounter sufficient conceptual complexity and intellectual depth to prepare them for reading 'academic texts', as the course advertises, they will certainly not find this in the input texts in Unit 4.

The text designated for extended reading (in the 'Reading and Writing' lesson, Section 4c, entitled 'Ethical decisions') has a magazine article-style tint and is headed 'Sporting hero or drug cheat?' It recounts the story of Ben Johnson's disgrace, opening with his 1988 new world record at the Seoul Olympics; outlining his failed drugs test and subsequent punishment, his 'sad' later career and second drugs test failure; and closing with the comment that 'Today, [Johnson] still believes the decision was unfair.' At mid-point the text includes the sentence 'Johnson was the unlucky one who got caught.' This sentence immediately follows a line stating that Johnson's coach 'said that many athletes took drugs, including some of the eight 100-metre finalists at Seoul', but it is not entirely clear whether the sentence is relaying the opinion of the coach or being given the sanction of the text. In one sense, what does this matter? The ensuing activities create plenty of opportunities for the students to discuss the text, 
and surely therefore to tease these kinds of meanings out. Except that the materials (no doubt inadvertently) work against rather than encourage much sensitive meaningmaking and debate. The students are asked for their own opinions, partially no doubt to 'personalize the topic' (C21 Introduction), but other than being required to listen to the opinions of their peers, they are offered no structured arguments and counterarguments, and no ethical frameworks are posited. The teacher, in turn, is given no support in the Teacher's Book (Mascull, 2016) to enrich, extend and differentiate, as the guidance restricts itself to very basic instructions, mainly involving eliciting from the students further examples (i.e. of cheating). What the teacher really needs at this point, I would suggest, are worked-out ideas of how to encourage students to use what language they already know, and the target language of the unit, to discuss such 'ethical decisions' with as much sophistication as their current language-level will allow.

Like its many competitors, C21 is visually populated with 'beautiful people', representing a range of ethnicities and a good gender balance, but with a conspicuous absence of people with disabilities. The 'characters' featured in our Unit 4 sample (including of course the four people in the section entitled 'High achievers') are without exception physically able, are of optimum weight, clear-skinned, with perfect smiles if they are shown smiling, and dressed in Western casual, smart-casual or businesscasual clothing. They look engaged, they look engaging and they all look like they know who they are, where they are going and what the rewards will be. There is, I think, a pernicious link between the tendency in Future 2 textbooks to foster personalized student responses, often unsupported 'opinions' framed in individualistic narrative contexts (Kullman, 2013), with a ubiquitous aspirational, consumerist - one could say, neoliberal - 'messaging' in text and image choice. As Gray and Block have argued in the context of their research on ELT textbooks, there has been a clear trend since the 1970s away from 'class-based and other collective identity inscriptions' and in its place an 'overwhelming focus on consumerism and the lifestyles of a cosmopolitan middle class' (2014: 47). This amounts, they argue 'to little more than a celebration of neoliberal ideology' (ibid.). It is all a little too shallow, displaying style over substance. To return to the Prologue, it is a little too Irwin (Bennett, 2004).

\section{Conclusion}

I am 'complicit, imbricated and compromised' (Ball, 2012): I do not forget that I originally commissioned this course, and can certainly not stand apart from any of the negative criticisms I have made of the materials. Nor do I take any credit for the many aspects of C21 that I think work well, which are down to the excellence of the writers, editors and designers. But now we need to find ways forward. The question for me, if I were to commission this kind of package again, is: what would I do differently? What principles would I start from in order to create a Future 3 course?

The Cambridge principles, discussed above, would provide the starting place and give excellent direction. But the choice was made, in the course of the research stage of the design of these principles, to analyse 'high-quality materials ... from a set of high-performing jurisdictions around the world' (Cambridge Assessment, 2016: 5). To fully understand the reality of textbook creation and use in the UK context and across the spectrum of school systems globally, and to provide fully evidenced criteria for their improvement, the next step is to look at a far more representative range of materials - those from low-, middle- as well as high-ranking countries, and from school systems that do not fit within any neat categorization. Equally, this analysis should have a clear and defensible theoretical framework, rather than a set of implicit quality 
judgements, and for that framework I have argued here that the 'three futures' heuristic would be a powerful tool.

In my experience of Future 2-style textbook publishing, and because of very real market and political pressures, insufficient energy tends to go into thinking about exactly what it is the teacher should be teaching and how the students should be learning, and if this what and how are together the best use of curriculum time. In this way, neither knowledge nor skills are presented and scaffolded in an optimal way. Students may be having a better time in class but they may be learning less than it is their right to learn. A Future 3 approach, by contrast, would involve a healthy commitment to powerful knowledge and a concomitant belief in the efficacy of subject-specialist teaching. Given the current impetus towards knowledge-led curricula and materials from the groups discussed at the outset, however vexed the politics, it may be that the time is right to start putting these principles into publishing practice.

\section{Notes on the contributor}

Nicky Platt is former Director of UCL IOE Press, a university press based at the UCL Institute of Education (IOE), and works also for the IOE on international materials development and curriculum projects. In the course of her career, Nicky has worked with many ministries of education, school systems and universities globally, developing educational and academic materials tailored to each country's specific needs. Nicky is Co-director of the Subject Specialism Research Group (SSRG).

\section{References}

Apple, M.W. (2014) Official Knowledge: Democratic education in a conservative age. 3rd ed. New York: Routledge.

Ball, S.J. (2012) Global Education Inc.: New policy networks and the neo-liberal imaginary. London: Routledge.

Ball, S.J. (2017) The Education Debate. 3rd ed. Bristol: Policy Press.

Bennett, A. (2004) The History Boys. London: Faber and Faber.

Biddulph, M., Lambert, D. and Balderstone, D. (2015) Learning to Teach Geography in the Secondary School: A companion to school experience. 3rd ed. London: Routledge.

Biesta, G. (2005) 'Against learning: Reclaiming a language for education in an age of learning'. Nordisk Pedagogik, 25, 54-66.

Biesta, G.J.J. (2017) The Rediscovery of Teaching. London: Routledge.

Cambridge Assessment (2016) The Cambridge Approach to Textbooks: Principles for designing high-quality textbook and resource materials. Cambridge: Cambridge Assessment.

Crace, J. (2006) 'Critical acclaim'. The Guardian, 17 October. Online. www.theguardian.com/ stage/2006/oct/17/theatre.schools (accessed 20 July 2018).

Crawford, K. and Foster, S. (2006) 'The political economy of history textbook publishing in England'. In Nicholls, J. (ed.) School History Textbooks across Cultures: International debates and perspectives. Oxford: Symposium Books, 93-104.

Cruddas, L. (2017) 'Foreword'. In The Question of Knowledge: Practicalities of a knowledge-based curriculum. Association of School and College Leaders and Parents and Teachers for Excellence, 6. Online. http://parentsandteachers.org.uk/application/files/3415/0816/0485/The_Question_of_ Knowledge_FINAL.pdf (accessed 8 February 2018).

Derry, J. (2018) 'What is educationally worthwhile knowledge? Revisiting the case for powerful knowledge'. In Guile, D., Lambert, D. and Reiss, M.J. (eds) Sociology, Curriculum Studies and Professional Knowledge: New perspectives on the work of Michael Young. London: Routledge, 84-96.

Eyre, C. (2018) 'Cutting spend on textbooks is a "false economy", says PA'. The Bookseller, 14 March. Online. www.thebookseller.com/news/cutting-spend-textbooks-false-economy-sayspa-749336 (accessed 29 May 2018). 
Foster, S. (2011) 'Dominant traditions in international textbook research and revision'. Education Inquiry, 2 (1), 5-20.

Garnet Education (2018) 'C21: English for the 21st century - The groundbreaking general English course for study, work and life'. Online. www.garneteducation.com/c21/ (accessed 6 January 2018).

Gibb, N. (2015) 'How to get more high-quality textbooks into classrooms' (speech to the Publishers Association, 17 November 2015). Online. www.gov.uk/government/speeches/how-to-get-morehigh-quality-textbooks-into-classrooms (accessed 23 January 2017).

Gibb, N. (2017) 'The importance of knowledge-based education' (speech to the Association of Schools and College Leaders, 19 October 2017). Online. www.gov.uk/government/speeches/ nick-gibb-the-importance-of-knowledge-based-education (accessed 6 January 2018).

Grammatosi, F. and Harwood, N. (2014) 'An experienced teacher's use of the textbook on an academic English course: A case study'. In Harwood, N. (ed.) English Language Teaching Textbooks: Content, consumption, production. Basingstoke: Palgrave Macmillan, 178-204.

Gray, J. (2010) The Construction of English: Culture, consumerism and promotion in the ELT global coursebook. Basingstoke: Palgrave Macmillan.

Gray, J. and Block, D. (2014) 'All middle class now? Evolving representations of the working class in the neoliberal era: The case of ELT textbooks'. In Harwood, N. (ed.) English Language Teaching Textbooks: Content, consumption, production. Basingstoke: Palgrave Macmillan, 45-71.

Hadley, G. (2014) 'Global textbooks in local contexts: An empirical investigation of effectiveness'. In Harwood, N. (ed.) English Language Teaching Textbooks: Content, consumption, production. Basingstoke: Palgrave Macmillan, 205-38.

Harwood, N. (2014) 'Content, consumption, and production: Three levels of textbook research'. In Harwood, N. (ed.) English Language Teaching Textbooks: Content, consumption, production. Basingstoke: Palgrave Macmillan, 1-41.

Independent Teacher Workload Review Group (2016) Eliminating Unnecessary Workload around Planning and Teaching Resources: Report of the Independent Teacher Workload Review Group. London: Department for Education.

Issitt, J. (2004) 'Reflections on the study of textbooks'. History of Education, 33 (6), 683-96.

Kullman, J. (2013) 'Telling tales: Changing discourses of identity in the "global" UK-published English language coursebook'. In Gray, J. (ed.) Critical Perspectives on Language Teaching Materials. Basingstoke: Palgrave Macmillan, 17-39.

Lambert, D. (1999) 'Exploring the use of textbooks in Key Stage 3 geography classrooms: A small-scale study'. Curriculum Journal, 10 (1), 85-105.

Lambert, D. (2018) 'The road to Future 3: The case of geography'. In Guile, D., Lambert, D. and Reiss, M.J. (eds) Sociology, Curriculum Studies and Professional Knowledge: New perspectives on the work of Michael Young. London: Routledge, 132-45.

Larson, J., Allen, A.-R. and Osborn, D. (2010) 'Curriculum and the publishing industry'. In Peterson, P., Baker, E. and McGaw, B. (eds) International Encyclopedia of Education. 3rd ed. Oxford: Elsevier, 368-73.

Lawes, S. (2017) 'Foreign languages'. In Standish, A. and Sehgal Cuthbert, A. (eds) What Should Schools Teach? Disciplines, subjects and the pursuit of truth. London: UCL Institute of Education Press, 37-48.

Lee, J. and Catling, S. (2016) 'Some perceptions of English geography textbook authors on writing textbooks'. International Research in Geographical and Environmental Education, 25 (1), 50-67.

Lidstone, J. (1992) 'In defence of textbooks'. In Naish, M. (ed.) Geography and Education: National and international perspectives. London: Institute of Education, 177-93.

Marsden, W.E. (2001) The School Textbook: Geography, history and social studies. London: Woburn Press.

Mascull, B. (2016) C21: English for the 21st century: Level 2 teacher's book. Reading: Garnet Education.

Moore, R. (2004) 'Cultural capital: Objective probability and the cultural arbitrary'. British Journal of Sociology of Education, 25 (4), 445-56.

Morgan, J. (2018) 'Michael Young, knowledge and the crises of capitalism'. In Guile, D., Lambert, D. and Reiss, M.J. (eds) Sociology, Curriculum Studies and Professional Knowledge: New perspectives on the work of Michael Young. London: Routledge, 109-20.

Nicholls, J. (2005) 'The philosophical underpinnings of school textbook research'. Paradigm, 3 (1), 24-35.

Oates, T. (2014) Why Textbooks Count: A policy paper. Cambridge: Cambridge Assessment. 
O'Driscoll, N. and Hughes, J. (2016) C21: English for the 21st century: Level 2 course book. Reading: Garnet Education.

Publishers Association (2016a) 'Textbook Challenge campaign news'. Press release, 25 November.

Publishers Association (2016b) 'Textbook Challenge Campaign facts'. Online. www.textbookchallenge.uk/facts.html (accessed 23 January 2017).

Publishers Association (2017) 'UK Publishing has record year up $7 \%$ to $£ 4.8 b n$ '. Press release, 26 April. Online. www.publishers.org.uk/news/press-releases/2017/uk-publishing-has-recordyear-up-7-to-48bn/ (accessed 29 May 2018).

Reynolds, D. and Farrell, S. (1996) Worlds Apart? A review of international surveys of educational achievement involving England. London: HMSO.

Sehgal Cuthbert, A. and Standish, A. (2017) 'Conclusion'. In Standish, A. and Sehgal Cuthbert, A. (eds) What Should Schools Teach? Disciplines, subjects and the pursuit of truth. London: UCL Institute of Education Press.

Spielman, A. (2017) 'HMCl's commentary: Recent primary and secondary curriculum research'. Online. https://www.gov.uk/government/speeches/hmcis-commentary-october-2017 (accessed 23 August 2018).

Thornbury, S. (2013) 'Resisting coursebooks'. In Gray, J. (ed.) Critical Perspectives on Language Teaching Materials. Basingstoke: Palgrave Macmillan, 204-23.

Watt, H. and Newell, C. (2011) 'Exam boards' relationship with textbook publishers to come under scrutiny'. The Telegraph, 8 December. Online. www.telegraph.co.uk/education/ secondaryeducation/8940810/Exam-boards-relationship-with-textbook-publishers-to-comeunder-scrutiny.html (accessed 1 February 2018).

Young, M.F.D. (ed.) (1971) Knowledge and Control: New directions for the sociology of education. London: Collier Macmillan.

Young, M.F.D. (2008) Bringing Knowledge Back In: From social constructivism to social realism in the sociology of education. London: Routledge.

Young, M. (2017) Book launch speech given at the UCL Institute of Education, London, 22 November 2017.

Young, M., Lambert, D., Roberts, C. and Roberts, M. (2014) Knowledge and the Future School: Curriculum and social justice. London: Bloomsbury Academic.

Young, M. and Muller, J. (2010) 'Three educational scenarios for the future: Lessons from the sociology of knowledge'. European Journal of Education, 45 (1), 11-27.

Young, M. and Muller, J. (2016) Curriculum and the Specialization of Knowledge: Studies in the sociology of education. London: Routledge. 